\title{
FORMULASI LOTION EKSTRAK ETANOL KULIT BUAH MANGGIS (Garcinia mangostana L.) DENGAN VARIASI CETIL ALKOHOL KONSENTRASI 0,5\% DAN 1\%
}

\section{FORMULATION OF LOTION FROM ETHANOL EXTRACT OF MANGOSTEEN RIND (Garcinia mangostana L.) WITH VARIATION OF CETHYL ALCOHOL CONCENTRATION $0,5 \%$ AND $1 \%$}

\author{
Sulistiorini Indriaty, Aisya Madina, Rima Yulia Senja \\ Akademi Farmasi Muhammadiyah Cirebon \\ Jalan Cideng Indah No. 03, Cirebon \\ Email :lovely_kalila@yahoo.co.id
}

\begin{abstract}
ABSTRAK
Kulit buah manggis (Garcinia mangostana L.) memiliki kandungan senyawa xanton yang berkhasiat sebagai antioksidan. Penelitian ini bertujuan untuk membuat sediaan lotion dengan zat aktif ekstrak etanol kulit buah manggis $1 \%$ dengan memvariasikan konsentrasi cetil alkohol 0,5\% dan 1\%. Ekstrak etanol kulit buah manggis dibuat dengan cara maserasi menggunakan pelarut etanol $96 \%$ dengan rendemen yang dihasilkan sebanyak 15,87\%. Uji stabilitas dilakukan dengan metode cycling test selama 12 hari pada suhu $\pm 4{ }^{\circ} \mathrm{C}$ dan $\pm 40{ }^{\circ} \mathrm{C}$ selama 24 jam dengan parameter pengamatan meliputi uji organoleptik, uji homogenitas, uji $\mathrm{pH}$, uji daya sebar dan identifikasi tipe emulsi. Hasil penelitian bau lotion tidak stabil terhitung pada hari ke-4, warna lotion stabil berwarna kuning, $\mathrm{pH}$ berkisar 6-7, homogenitas lotion stabil tidak menunjukkan adanya partikel padat, daya sebar yang tidak stabil dengan diameter yang berkisar $3 \mathrm{~cm}-9 \mathrm{~cm}$, dan tipe emulsi minyak dalam air. Berdasarkan hasil penelitian dapat disimpulkan bahwa lotion stabil pada parameter homogenitas, $\mathrm{pH}$ dan tipe emulsi tetapi tidak stabil pada parameter organoleptis dan daya sebar.
\end{abstract}

Kata kunci : Garcinia mangostana L., lotion, cycling test

\begin{abstract}
Mangosteen rind (Garcinia mangostana L.) contain xanton which used as antioxydant. Goal of this research is for make a lotion with substance $1 \%$ ethanol extract of mangosteen rind with concentration $0,5 \%$ and $1 \%$ of cethyl alcohol. Ethanol extract of mangosteen rind made by maseration used ethanol $96 \%$ as solvent with rendemen value is $15,87 \%$. Stability test have been done by cycling test during 12 days at temperature $\pm 4{ }^{\circ} \mathrm{C}$ and $\pm 40{ }^{\circ} \mathrm{C}$ in 24 hours with observation parameter are organoleptic test, homogenity test, $\mathrm{pH}$ test, dispersion test and emulsion type's identification. Result of this research are unstable smell since 4rd days, color of lotion is stable in yellow, $\mathrm{pH}$ amount 6-7, lotion's homogenity didn't show solids particle, dispersive area unstable with diameter around $3 \mathrm{~cm}-9 \mathrm{~cm}$, and type of emulsion is oil in water. Based on result of research can take conclusion that the lotion stable on homogenity, $\mathrm{pH}$, and emulsion type's parameter but unstable on organoleptic and dispersion's parameter.
\end{abstract}

Keywords : Garcinia mangostana L., lotion, cycling test 


\section{PENDAHULUAN}

Kulit merupakan "selimut" yang menutupi permukaan tubuh dan memiliki fungsi utama sebagai pelindung dari berbagai macam gangguan dan rangsangan luar. Salah satu masalah pada kulit yaitu penuaan dini. Faktor yang sangat mempengaruhi penuaan dini adalah sinar matahari, khususnya sinar UV yang dapat menyebabkan kulit cepat kering, keriput, kasar, dan menyebabkan kerusakan lain (Tranggono dan Latifah, 2007).

Kosmetik pelembab perlu dikenakan terutama pada kulit kering atau kulit normal yang cenderung kering, terutama jika si pemakai akan lama berada di dalam lingkungan yang mengeringkan kulit. Disinilah kosmetik pelembab kulit diperlukan untuk mencegah dehidrasi kulit yang menyebabkan kekeringan dan retak-retak pada kulit serta akibat-akibat buruknya (Tranggono dan Latifah, 2007).

Kosmetik pelembab kulit salah satunya adalah lotion. Menurut Mitsui (1997), lotion merupakan campuran dari air, alkohol, emolien, humektan, bahan pengental, bahan pengawet dan bahan pewangi. Sediaan lotion yang dikombinasikan dengan antioksidan dapat digunakan untuk mengatasi masalah penuaan dini.

Kulit buah manggis mengandung senyawa xanton. Senyawa ini efektif mengikat radikal bebas di dalam tubuh. Antioksidan ini dapat membantu mengobati kerusakan sel akibat oksidasi radikal bebas, menghambat proses penuaan, dan mencegah penyakit degeneratif (Mardiana, 2013).

Dalam formulasi lotion, digunakan kombinasi cetil alkohol sebagai emulsifying agent dengan konsentrasi 2-10\%. Cetil alkohol banyak digunakan dalam sediaan semi solid, termasuk dalam sediaan lotion. Dalam perannya sebagai emulsifying agent, cetil alkohol mampu membuat lotion dengan viskositas yang baik sehingga lotion dapat melekat pada kulit lebih lama, meresap dalam kulit dan membuat efek repelan dalam lotion lebih lama. Bahan ini juga dapat digunakan sebagai emolient yang berguna sebagai bahan pengoklusi di permukaan kulit yang mampu menahan air agar tetap berada di statrum korneum sehingga kulit akan terasa lembab (Unvala dalam Mutakilah, 2009).

Penelitian ini bertujuan untuk membuat lotion dari ekstrak etanol kulit buah manggis dengan variasi cetil alkohol $0,5 \%$ dan $1 \%$, mengetahui stabilitas formula ekstrak etanol kulit buah manggis dengan metode cycling test berupa uji organoleptik, uji homogenitas, uji $\mathrm{pH}$, uji daya sebar dan identifikasi tipe emulsi.

\section{METODE PENELITIAN}

\section{Alat dan Bahan}

Alat yang digunakan pada penelitian ini adalah Timbangan analitik CP214 (Ohaus); Beaker glass (Pyrex); Gelas ukur (Pyrex); Tangas air; Cawan porselen (Pyrex); pH meter (Mettler Toledo); Lemari pendingin (Sharp); Oven (tipe FCD-2000); Mixer (Miyako).

Bahan yang digunakan diantaranya Kulit buah manggis (PT. Bina Shifa), Asam stearat (Pro teknis CV. Mustika Lab), Cetil alkohol (Pro Teknis CV. Brataco), Paraffin cair (Pro Teknis CV. Mustika Lab), Glicerin (Pro Teknis CV. Mustika Lab), Triethanolamin (Pro Teknis CV. Global), Dinatrium EDTA (Pro Teknis CV. Mustika Lab), Sodium metabisulfit (Pro Teknis CV. Mustika Lab), Asam benzoat (Pro Teknis CV. Brataco), Parfum (Pro Teknis CV. Sanitas), Aquadest (Pro Teknis CV. Brataco).

\section{Jalannya Penelitian}

1. Pengujian Pendahuluan

Makroskopik

Simplisia kulit buah manggis diamati bentuk, warna, dan bau. Pengamatan dilakukan di Laboratorium Farmakognosi Akademi Farmasi Muhammadiyah Cirebon. 
Mikroskopik

Serbuk kulit buah manggis diidentifikasi secara mikroskopik. Pengamatan dilakukan di Laboratorium Farmakognosi Akademi Farmasi Muhammadiyah Cirebon.

\section{Pembuatan Ekstrak}

Timbang $200 \mathrm{~g}$ serbuk simplisia kulit manggis, masukkan ke dalam bejana lalu basahi dengan $1500 \mathrm{ml}$ etanol $96 \%$, tutup bejana diamkan selama 5 hari terlindung dari cahaya sambil sering diaduk. Setelah 5 hari campuran kulit manggis dan etanol $96 \%$ diperas, dicuci ampasnya dengan etanol $96 \%$ sebanyak $500 \mathrm{ml}$. Lalu disimpan dalam bejana tertutup selama 2 hari. Maserat yang telah diinapkan selama 2 hari dipekatkan di rotary evaporator sampai 1/3 bagian, kemudian diuapkan di penangas air sampai diperoleh ekstrak kental kulit manggis (Anonim, 1979). Rendemen ekstrak yang dihasilkan adalah $15,87 \%$.

\section{Pembuatan Lotion}

Timbang masing-masing bahan yang diperlukan. Bahan-bahan yang termasuk fase minyak (asam stearat, paraffin cair, cetil alkohol) dan fase air (glicerin, triethanolamin, dinatrium EDTA, sodium metabisulfit, asam benzoat dan aquadest) dimasukkan ke dalam cawan porselen secara terpisah. Fase minyak dan fase air dipanaskan dan diaduk pada suhu $50{ }^{\circ} \mathrm{C}$ selama $\pm 10-15$ menit secara terpisah hingga homogen. Campurkan fase air dan fase minyak dalam keadaan panas, aduk hingga terbentuk emulsi. Tambahkan ekstrak etanol kulit buah manggis, aduk hingga homogen. Masukkan lotion ke dalam kemasan. Formula lotion ekstrak etanol kulit buah manggis dapat dilihat pada Tabel. I

Tabel I. Formula lotion ekstrak etanol kulit buah manggis

\begin{tabular}{|c|c|c|c|c|c|}
\hline \multirow{2}{*}{ Bahan } & \multicolumn{3}{|c|}{ Jumlah (\%) } & \multirow[b]{2}{*}{ Basis } & \multirow[b]{2}{*}{ II } \\
\hline & Formula I & Formula II & Basis I & & \\
\hline $\begin{array}{l}\text { Ekstrak etanol kulit } \\
\text { buah manggis }\end{array}$ & 1 & 1 & - & & - \\
\hline Asam stearat & 1 & 1 & 1 & & 1 \\
\hline Cetil alkohol & 0,5 & 1 & 0,5 & & 1 \\
\hline Paraffin cair & 2 & 2 & 2 & & 2 \\
\hline Glicerin & 2 & 2 & 2 & & 2 \\
\hline Triethanolamin & 0,5 & 0,5 & 0,5 & & 0,5 \\
\hline Asam benzoat & 0,2 & 0,2 & 0,2 & & 0,2 \\
\hline Dinatrium EDTA & 0,1 & 0,1 & 0,1 & & 0,1 \\
\hline Sodium metabisulfit & 0.1 & 0,1 & 0,1 & & 0.1 \\
\hline Oleum rosae & q.s & q.s & q.s & & q.s \\
\hline Aquadest ad & 100 & 100 & 100 & & 100 \\
\hline
\end{tabular}

\section{Evaluasi Sediaan Lotion}

Uji stabilitas dilakukan dengan metode cycling test selama 12 hari (6 siklus) pada suhu $4{ }^{\circ} \mathrm{C}$ dan $40{ }^{\circ} \mathrm{C}$ selama 24 jam. Pengamatan dilakukan pada hari ke-0, siklus ke-1 hingga ke-6. Parameter yang diamati pada pengujian ini yaitu :

4.1 Uji organoleptis

Uji organoleptis meliputi pengamatan bau dan warna dari sediaan lotion ekstrak etanol kulit buah manggis. 


\section{2 $\mathrm{Uji} \mathrm{pH}$}

Elektroda dicelupkan ke dalam lotion sampai $\mathrm{pH}$ meter menunjukkan pembacaan yang tetap. Dicatat hasil pembacaan skala dan setelah selesai pengujian dibilas dengan aquadest dan dikeringkan dengan tisu (Nova dalam Dewi, 2012).Hasil pengukuran $\mathrm{pH}$ sediaan memenuhi kriteria $\mathrm{pH}$ kulit yaitu dalam interval $\mathrm{pH}$ 4,5-6,5 (Anggraeni, 2008).

\subsection{Uji homogenitas}

Sediaan lotion diambil pada masing-masing formula secukupnya dan dioleskan pada plat kaca, diraba dan digosokkan. Massa lotion harus menunjukkan susunan homogen yaitu tidak terasa adanya bahan padat pada kaca (Nova dalam Dewi, 2012).

\subsection{Uji daya sebar}

Di atas kertas grafik yang sudah dilapisi plastik transparan diletakkan sebanyak 1 gram lotion kemudian ditutup dengan plastik transparan lain dan diukur diameternya dari lima titik sudut. Di atas lapisan lotion tersebut diletakkan beban 19 gram, untuk mencatat diameter lotion yang menyebar diamkan selama 1 menit. Kemudian ditambahkan kembali beban 20 gram diatas lotion, didiamkan selama 1 menit dan dicatat diameter lotion yang menyebar. Beban 20 gram selanjutnya ditambahkan kembali di atas lotion hingga beban maksimum di atas lotion seberat 99 gram, dan setiap kali beban ditambahkan di atas lotion didiamkan selama 1 menit dan dicatat diameter lotion yang menyebar (Izzati, 2014).

5.5 Identifikasi tipe emulsi

Dengan kertas saring

Bila emulsi diteteskan pada kertas saring, kertas saring menjadi basah maka tipe emulsi tersebut o/w, dan bila timbul noda minyak pada kertas maka emulsi tersebut tipe w/o (Syamsuni, 2006).

\section{Dengan pengenceran fase}

Setiap emulsi dapat diencerkan dengan fase externalnya. Dengan prinsip tersebut, emulsi tipe o/w dapat diencerkan dengan air sedangkan emulsi tipe w/o dapat diencerkan dengan minyak (Syamsuni, 2008).

\section{HASIL DAN PEMBAHASAN}

\section{Uji Makroskopik dan mikroskopik kulit buah manggis}

Uji makroskopik dan mikroskopik simplisia kulit buah manggis antara hasil penelitian dibandingkan dengan data pustaka yang berasal dari Farmakope Herbal. Hasil uji makroskopik dapat dilihat di Tabel II. 
Tabel. II. Hasil Uji Makroskopik Simplisia Kulit Buah Manggis

\begin{tabular}{lll}
\hline Pengamatan & \multicolumn{1}{c}{ Menurut Literatur } & \multicolumn{1}{c}{ Hasil Penelitian } \\
\hline Bau & Tidak berbau & Tidak berbau \\
Bentuk & $\begin{array}{l}\text { Berupa potongan padat, agak } \\
\text { keras, bentuk seperempat bola } \\
\text { atau setengah bola }\end{array}$ & $\begin{array}{l}\text { Berupa potongan padat, agak } \\
\text { keras, bentuk seperempat bola } \\
\text { atau setengah bola. }\end{array}$ \\
Warna & $\begin{array}{l}\text { Bagian luar berwarna cokelat } \\
\text { tua, bagian dalam cokelat, } \\
\text { bagian permukaan luar } \\
\text { berwarna kecokelatan sampai } \\
\text { cokelat kehitaman }\end{array}$ & $\begin{array}{l}\text { Bagian luar berwarna cokelat } \\
\text { tua, bagian dalam cokelat, } \\
\text { bagian permukaan luar } \\
\text { berwarna kecokelatan sampai } \\
\text { cokelat kehitaman }\end{array}$ \\
\hline
\end{tabular}

Pengujian makroskopik merupakan pengujian organoleptis dengan pengamatan yang meliputi bau, bentuk dan warna dari simplisia kulit buah manggis. Pengujian mikroskopik merupakan pengujian dengan menggunakan mikroskop yang bertujuan untuk mengidentifikasi ciri khas simplisia kulit buah manggis. Hasil uji makroskopik dan mikroskopik simplisia kulit buah manggis selanjutnya dibandingkan dengan data literatur (Anonim, 2008). Gambar mikroskopik serbuk kulit buah manggis dapat dilihat pada tabel III.

Tabel. III. Mikroskopik Serbuk Kulit Buah Manggis

\begin{tabular}{ll}
\hline Menurut Literatur & Hasil penelitian \\
\hline & \\
Parenkim Mesokarp & Parenkim Mesokarp \\
\hline
\end{tabular}

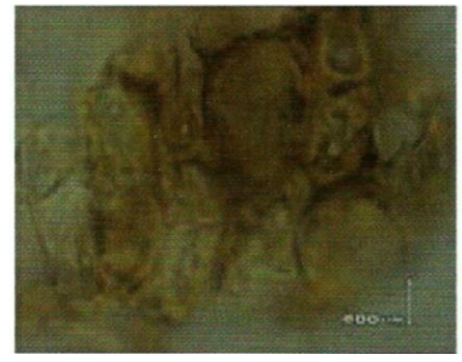

Periderm

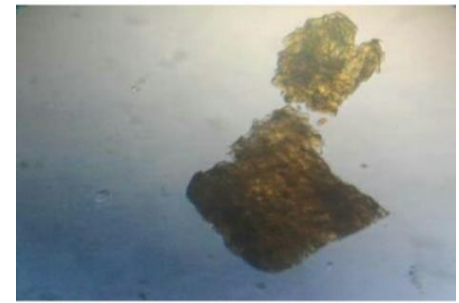

Periderm 


\section{Hasil Uji Stabilitas lotion ekstrak kulit buah manggis}

Stabilitas lotion ekstrak etanol kulit buah manggis dilakukan dengan metode Cycling test, dimana stabilitas sediaan lotion diamati pada suhu $4^{\circ} \mathrm{C}$ dan $40^{\circ} \mathrm{C}$ selama 6 siklus $(12$ hari) dengan parameter yang diamati yaitu organoleptis (bau dan warna), $\mathrm{pH}$, homogenitas dan daya sebar lotion dan pengujian tipe emulsi. Pada penyimpanan suhu $25^{\circ} \mathrm{C}$, bau lotion kedua formula cenderung stabil. Berdasarkan hasil pengamatan (Tabel IV.), bau dari oleum rosae masih tercium kuat hingga pengamatan pada hari ke-3, dan bau oleum rosae mulai hilang pada pengamatan hari ke-4. Lotion yang disimpan pada suhu $4^{\circ} \mathrm{C}$ dan $40^{\circ} \mathrm{C}$ mengalami penurunan bau dihari ke-4, perubahan dari bau yang kuat ke bau yang lemah. Hal ini kemungkinan disebabkan karena perubahan suhu yang ekstrim sehingga mempengaruhi komponen bahan dalam lotion yang sebagian besar merupakan fase minyak. Basis formula I dan II pun mengalami perubahan bau, hal ini menunjukkan bahwa ketidakstabilan bau berasal dari komponen dasar formula.

Hasil pengujian stabilitas warna, formula lotion cenderung stabil dari hari ke-0 sampai hari ke-12 seperti ditunjukkan pada Tabel. V. Apabila ada perubahan warna pada formula lotion menunjukkan adanya ketidakstabilan pada komponen dalam formula lotion .

Tabel IV. Hasil pengamatan bau

\begin{tabular}{cccccc}
\hline Suhu & Hari Ke- & Formula I & Formula II & Basis I & Basis II \\
\hline $25^{\circ} \mathrm{C}$ & 0 & ++ & ++ & ++ & ++ \\
$4{ }^{\circ} \mathrm{C}$ & 1 & ++ & ++ & ++ & ++ \\
& 3 & ++ & ++ & ++ & ++ \\
& 5 & + & + & + & + \\
& 7 & + & + & + & + \\
& 9 & + & + & + & + \\
$40^{\circ} \mathrm{C}$ & 11 & + & + & + & + \\
& 2 & + & ++ & ++ & ++ \\
& 4 & + & + & + & + \\
& 6 & + & + & + & + \\
& 8 & + & + & + & + \\
& 10 & + & + & + & + \\
& 12 & + & + & + & + \\
\hline
\end{tabular}

Keterangan :

++ : Bau Khas Kuat Oleum Rosae

+ : Bau Khas Lemah Oleum Rosae

Adanya perubahan warna bisa jadi menunjukkan adanya interaksi kimiawi antara komponenkomponen bahan dalam formula lotion.

Selain parameter organoleptis, kestabilan $\mathrm{pH}$ pun menjadi syarat suatu sediaan lotion dianggap baik. $\mathrm{pH}$ sediaan topikal dipersyaratkan berada dalam range 4,5-6,5. Apabila di bawah $\mathrm{pH}$ 4,5 maka ada kecenderungan formula dapat mengiritasi kulit karena bersifat asam, sedangkan apabila lotion memiliki pH di atas 6,5 (basa) maka memiliki kecenderungan dapat menyebabkan kulit menjadi busik (Izzati, 2014). Kestabilan pH akan membantu menghindari atau mencegah kerusakan produk selama penyimpanan. 
Tabel V. Hasil pengamatan warna

\begin{tabular}{cccccc}
\hline Suhu & Hari Ke- & Formula I & Formula II & Basis I & Basis II \\
\hline $25^{\circ} \mathrm{C}$ & 0 & $\mathrm{~K}$ & $\mathrm{~K}$ & $\mathrm{P}$ & $\mathrm{P}$ \\
$4^{\circ} \mathrm{C}$ & 1 & $\mathrm{~K}$ & $\mathrm{~K}$ & $\mathrm{P}$ & $\mathrm{P}$ \\
& 3 & $\mathrm{~K}$ & $\mathrm{~K}$ & $\mathrm{P}$ & $\mathrm{P}$ \\
& 5 & $\mathrm{~K}$ & $\mathrm{~K}$ & $\mathrm{P}$ & $\mathrm{P}$ \\
& 7 & $\mathrm{~K}$ & $\mathrm{~K}$ & $\mathrm{P}$ & $\mathrm{P}$ \\
& 9 & $\mathrm{~K}$ & $\mathrm{~K}$ & $\mathrm{P}$ & $\mathrm{P}$ \\
$40^{\circ} \mathrm{C}$ & 11 & $\mathrm{~K}$ & $\mathrm{~K}$ & $\mathrm{P}$ & $\mathrm{P}$ \\
& 2 & $\mathrm{~K}$ & $\mathrm{~K}$ & $\mathrm{P}$ & $\mathrm{P}$ \\
& 4 & $\mathrm{~K}$ & $\mathrm{~K}$ & $\mathrm{P}$ & $\mathrm{P}$ \\
& 6 & $\mathrm{~K}$ & $\mathrm{~K}$ & $\mathrm{P}$ & $\mathrm{P}$ \\
& 8 & $\mathrm{~K}$ & $\mathrm{~K}$ & $\mathrm{P}$ & $\mathrm{P}$ \\
& 10 & $\mathrm{~K}$ & $\mathrm{~K}$ & $\mathrm{P}$ & $\mathrm{P}$ \\
& 12 & $\mathrm{~K}$ & $\mathrm{~K}$ & $\mathrm{P}$ & $\mathrm{P}$ \\
\hline
\end{tabular}
Keterangan :
$\mathrm{K}$ : Kuning
$\mathrm{P} \quad$ : Putih

Berdasarkan hasil pengujian pH (Tabel VI), baik formula I maupun formula II berada pada range 6-7. Meskipun ada penurunan $\mathrm{pH}$ pada hari tertentu, namun secara keseluruhan masih memenuhi syarat $\mathrm{pH}$ sediaan topikal yang baik yaitu 4,5-6,5 (izzati, 2014).

Tabel VI. Hasil pengamatan pH

\begin{tabular}{cccccc}
\hline Suhu & Hari Ke- & Formula I & Formula II & Basis I & Basis II \\
\hline $25^{\circ} \mathrm{C}$ & 0 & 6,57 & 7,03 & 6,93 & 6,42 \\
& 1 & 6,60 & 7,06 & 6,81 & 6,56 \\
$4{ }^{\circ} \mathrm{C}$ & 3 & 6,70 & 7,01 & 7,04 & 6,73 \\
& 5 & 6,82 & 7,16 & 7,09 & 6,65 \\
& 7 & 6,68 & 7,01 & 6,91 & 6,59 \\
& 9 & 6,58 & 6,81 & 6,91 & 6,50 \\
$40{ }^{\circ} \mathrm{C}$ & 11 & 6,58 & 6,82 & 6,97 & 6,56 \\
& 2 & 6,57 & 6,92 & 6,91 & 6,62 \\
& 4 & 6,69 & 7,02 & 7,00 & 6,61 \\
& 6 & 6,67 & 7,08 & 6,56 & 6,83 \\
& 8 & 6,63 & 7,03 & 6,96 & 6,62 \\
& 10 & 6,78 & 7,24 & 7,07 & 6,78 \\
& 12 & 6,20 & 6,67 & 6,59 & 6,40 \\
\hline
\end{tabular}

Pengamatan terhadap homogenitas lotion (Tabel.VII) menunjukan jika kedua formula lotion menunjukkan struktur yang homogen hingga hari terakhir pengamatan. Homogenitas ditandai dengan tidak adanya partikel kasar atau gumpalan partikel ketika lotion dioleskan di permukaan kaca objek. Pada pengujian daya sebar, ke-4 lotion sudah memenuhi persyaratan daya sebar lotion yang baik dengan diameter 5-7 cm (Tabel IX). 
Tabel VII. Hasil Uji homogenitas

\begin{tabular}{cccccc}
\hline Suhu & Hari Ke- & Formula I & Formula II & Basis I & Basis II \\
\hline $25^{\circ} \mathrm{C}$ & 0 & Homogen & Homogen & Homogen & Homogen \\
& 1 & Homogen & Homogen & Homogen & Homogen \\
& 3 & Homogen & Homogen & Homogen & Homogen \\
$4{ }^{\circ} \mathrm{C}$ & 5 & Homogen & Homogen & Homogen & Homogen \\
& 7 & Homogen & Homogen & Homogen & Homogen \\
& 9 & Homogen & Homogen & Homogen & Homogen \\
& 11 & Homogen & Homogen & Homogen & Homogen \\
& 2 & Homogen & Homogen & Homogen & Homogen \\
$40{ }^{\circ} \mathrm{C}$ & 4 & Homogen & Homogen & Homogen & Homogen \\
& 6 & Homogen & Homogen & Homogen & Homogen \\
& 8 & Homogen & Homogen & Homogen & Homogen \\
& 10 & Homogen & Homogen & Homogen & Homogen \\
& 12 & Homogen & Homogen & Homogen & Homogen
\end{tabular}

Pengujian tipe emulsi dilakukan dengan cara pengenceran fase dan dengan cara penetesan ke kertas saring. Pengujian tipe emulsi dengan cara pengenceran, dimana emulsi dapat diencerkan dengan fase eksternalnya. Apabila diencerkan dengan air dan di kocok sediaan homogen, maka fase eksternal lotion tersebut adalah air, maka tipe emulsi minyak dalam air (m/a). Pengujian tipe emulsi dengan kertas saring, dilakukan dengan meneteskan ke kertas saring, hasil penelitian menunjukkan tidak terdapat noda minyak di kertas saring menandakan tipe lotion minyak dalam air (m/a). Tipe emulsi kedua formula ini stabil sejak hari ke-0 sampai dengan hari ke 12 setelah uji cycling test yaitu memiliki tipe emulsi m/a. Pengujian terhadap tipe emulsi dilakukan untuk menentukan lotion yang dibuat termasuk kedalam tipe emulsi minyak dalam air atau air dalam minyak. Sediaan lotion yang baik adalah sediaan lotion dengan tipe emulsi minyak dalam air sehingga mudah untuk dicuci dengan air.

Tabel VIII. Hasil Uji tipe emulsi

\begin{tabular}{cccccc}
\hline Suhu & Hari Ke- & Formula I & Formula II & Basis I & Basis II \\
\hline $25{ }^{\circ} \mathrm{C}$ & 0 & $\mathrm{~m} / \mathrm{a}$ & $\mathrm{m} / \mathrm{a}$ & $\mathrm{m} / \mathrm{a}$ & $\mathrm{m} / \mathrm{a}$ \\
& 1 & $\mathrm{~m} / \mathrm{a}$ & $\mathrm{m} / \mathrm{a}$ & $\mathrm{m} / \mathrm{a}$ & $\mathrm{m} / \mathrm{a}$ \\
$4{ }^{\circ} \mathrm{C}$ & 3 & $\mathrm{~m} / \mathrm{a}$ & $\mathrm{m} / \mathrm{a}$ & $\mathrm{m} / \mathrm{a}$ & $\mathrm{m} / \mathrm{a}$ \\
& 5 & $\mathrm{~m} / \mathrm{a}$ & $\mathrm{m} / \mathrm{a}$ & $\mathrm{m} / \mathrm{a}$ & $\mathrm{m} / \mathrm{a}$ \\
& 7 & $\mathrm{~m} / \mathrm{a}$ & $\mathrm{m} / \mathrm{a}$ & $\mathrm{m} / \mathrm{a}$ & $\mathrm{m} / \mathrm{a}$ \\
& 9 & $\mathrm{~m} / \mathrm{a}$ & $\mathrm{m} / \mathrm{a}$ & $\mathrm{m} / \mathrm{a}$ & $\mathrm{m} / \mathrm{a}$ \\
& 11 & $\mathrm{~m} / \mathrm{a}$ & $\mathrm{m} / \mathrm{a}$ & $\mathrm{m} / \mathrm{a}$ & $\mathrm{m} / \mathrm{a}$ \\
$40{ }^{\circ} \mathrm{C}$ & 2 & $\mathrm{~m} / \mathrm{a}$ & $\mathrm{m} / \mathrm{a}$ & $\mathrm{m} / \mathrm{a}$ & $\mathrm{m} / \mathrm{a}$ \\
& 4 & $\mathrm{~m} / \mathrm{a}$ & $\mathrm{m} / \mathrm{a}$ & $\mathrm{m} / \mathrm{a}$ & $\mathrm{m} / \mathrm{a}$ \\
& 6 & $\mathrm{~m} / \mathrm{a}$ & $\mathrm{m} / \mathrm{a}$ & $\mathrm{m} / \mathrm{a}$ & $\mathrm{m} / \mathrm{a}$ \\
& 8 & $\mathrm{~m} / \mathrm{a}$ & $\mathrm{m} / \mathrm{a}$ & $\mathrm{m} / \mathrm{a}$ & $\mathrm{m} / \mathrm{a}$ \\
& 10 & $\mathrm{~m} / \mathrm{a}$ & $\mathrm{m} / \mathrm{a}$ & $\mathrm{m} / \mathrm{a}$ & $\mathrm{m} / \mathrm{a}$ \\
& 12 & $\mathrm{~m} / \mathrm{a}$ & $\mathrm{m} / \mathrm{a}$ & $\mathrm{m} / \mathrm{a}$ & $\mathrm{m} / \mathrm{a}$ \\
\hline
\end{tabular}

Keterangan :

$\mathrm{m} / \mathrm{a}$ : Minyak dalam air 
Tabel IX. Hasil pengujian daya sebar lotion

\begin{tabular}{|c|c|c|c|c|c|c|}
\hline \multirow[b]{2}{*}{ Suhu } & \multirow[b]{2}{*}{ Hari ke- } & \multirow[b]{2}{*}{ Sampel } & \multicolumn{4}{|c|}{ Diameter $(\mathrm{cm})$} \\
\hline & & & $\begin{array}{l}\text { Tanpa } \\
\text { Beban }\end{array}$ & $\begin{array}{l}\text { Beban } \\
19 \text { gram }\end{array}$ & $\begin{array}{l}\text { Beban } \\
20 \text { gram }\end{array}$ & $\begin{array}{c}\text { Beban } \\
50 \text { gram }\end{array}$ \\
\hline \multirow{4}{*}{$25^{\circ} \mathrm{C}$} & \multirow{4}{*}{0} & Formula I & 5,38 & 6,155 & 7,06 & 7,35 \\
\hline & & Formula II & 3,03 & 4,88 & 5,90 & 6,56 \\
\hline & & Basis I & 6,49 & 7,845 & 8,00 & 8,62 \\
\hline & & Basis II & 6.04 & 7,07 & 7,23 & 7,65 \\
\hline \multirow[t]{24}{*}{$4^{\circ} \mathrm{C}$} & \multirow[t]{4}{*}{1} & Formula I & 3,61 & 5,62 & 6,17 & 6,71 \\
\hline & & Formula II & 3,16 & 5,97 & 6,70 & 7,49 \\
\hline & & Basis I & 6,31 & 7,14 & 7,55 & 7,65 \\
\hline & & Basis II & 4,54 & 6,74 & 7,43 & 7,81 \\
\hline & \multirow[t]{4}{*}{3} & Formula I & 9,32 & 9,49 & 9,65 & 9,24 \\
\hline & & Formula II & 3,82 & 5,92 & 7,95 & 8,38 \\
\hline & & Basis I & 6,21 & 7,41 & 7,85 & 8,13 \\
\hline & & Basis II & 5,14 & 7,54 & 8,64 & 9,00 \\
\hline & \multirow[t]{4}{*}{5} & Formula I & 8,88 & 9,40 & 9,80 & 9,78 \\
\hline & & Formula II & 2,71 & 5,28 & 6,04 & 6,82 \\
\hline & & Basis I & 5,97 & 7,31 & 8,21 & 8,62 \\
\hline & & Basis II & 3,21 & 6,02 & 7,61 & 8,03 \\
\hline & \multirow[t]{4}{*}{7} & Formula I & 7,43 & 8,59 & 9,02 & 9,35 \\
\hline & & Formula II & 3,35 & 5,44 & 6,57 & 7,05 \\
\hline & & Basis I & 4,76 & 6,70 & 7,77 & 8,44 \\
\hline & & Basis II & 3,22 & 4,97 & 5,71 & 6,56 \\
\hline & \multirow[t]{4}{*}{9} & Formula I & 6,86 & 8,69 & 9,35 & 9,70 \\
\hline & & Formula II & 2,43 & 5,20 & 5,92 & 6,46 \\
\hline & & Basis I & 7,84 & 8,45 & 9,10 & 9,52 \\
\hline & & Basis II & 3,98 & 6,23 & 7,71 & 8,72 \\
\hline & \multirow[t]{4}{*}{11} & Formula I & 5,69 & 8,85 & 9,28 & 9,58 \\
\hline & & Formula II & 2,52 & 5,27 & 5,56 & 6,11 \\
\hline & & Basis I & 5,77 & 7,75 & 8,95 & 9,27 \\
\hline & & Basis II & 5,65 & 7,42 & 8,86 & 8,96 \\
\hline \multirow[t]{24}{*}{$40^{\circ} \mathrm{C}$} & \multirow[t]{4}{*}{2} & Formula I & 5,44 & 6,46 & 7,06 & 7,27 \\
\hline & & Formula II & 3,89 & 6,02 & 6,58 & 6,63 \\
\hline & & Basis I & 5,06 & 7,32 & 8,10 & 9,05 \\
\hline & & Basis II & 4,12 & 5,77 & 6,36 & 6,91 \\
\hline & \multirow[t]{4}{*}{4} & Formula I & 6,92 & 8,21 & 8,86 & 9,37 \\
\hline & & Formula II & 2,93 & 5,40 & 6,01 & 6,52 \\
\hline & & Basis I & 5,99 & 8,43 & 8,87 & 8,98 \\
\hline & & Basis II & 4,09 & 6,23 & 7,435 & 8,03 \\
\hline & \multirow[t]{4}{*}{6} & Formula I & 5,94 & 8,35 & 8,61 & 9,19 \\
\hline & & Formula II & 2,58 & 5,35 & 5,84 & 6,71 \\
\hline & & Basis I & 6,17 & 7,59 & 8,27 & 8,85 \\
\hline & & Basis II & 3,71 & 6,55 & 7,55 & 7,96 \\
\hline & \multirow[t]{4}{*}{8} & Formula I & 6,01 & 8,43 & 9,37 & 9,32 \\
\hline & & Formula II & 4,08 & 6,02 & 6,75 & 7,26 \\
\hline & & Basis I & 5,44 & 7,58 & 8,21 & 8,46 \\
\hline & & Basis II & 3,42 & 5,87 & 7,45 & 7,52 \\
\hline & \multirow[t]{4}{*}{10} & Formula I & 6,38 & 8,49 & 9,48 & 9,64 \\
\hline & & Formula II & 3,36 & 5,89 & 6,68 & 7,38 \\
\hline & & Basis I & 8,14 & 9,18 & 9,30 & 9,54 \\
\hline & & Basis II & 6,54 & 8,50 & 9,35 & 9,47 \\
\hline & 12 & Formula I & 4,13 & 7,10 & 9,18 & 9,62 \\
\hline & & Formula II & 3,74 & 6,24 & 7,24 & 8,62 \\
\hline & & Basis I & 4,98 & 7,37 & 8,71 & 9,13 \\
\hline & & Basis II & 5,66 & 8,39 & 9,22 & 9,65 \\
\hline
\end{tabular}


Pengujian daya sebar lotion bertujuan untuk melihat apakah lotion mudah menyebar merata atau tidak saat diaplikasikan. Daya sebar lotion sangat penting karena akan mempengaruhi kemampuan penyebaran zat aktif dari lotion ketika diaplikasikan ke kulit. Lotion tidak boleh terlalu kental karena akan menyebabkan efek lengket ketika digunakan dan sulit mengalir ketika akan dikeluarkan dari wadah, namun lotion tidak boleh juga terlalu encer dikarenakan akan mudah tumpah ketika digunakan.

\section{KESIMPULAN}

Ekstrak etanol kulit buah manggis dapat diformulasikan dalam sediaan lotion dengan menggunakan variasi konsentrasi cetil alkohol $0,5 \%$ (formula I) dan $1 \%$ (formula II).

Sediaan lotion ekstrak etanol kulit buah manggis dengan menggunakan variasi konsentrasi cetil alkohol pada uji stabilitas dengan metode cycling test menunjukkan bahwa kedua formula lotion stabil pada parameter homogenitas, $\mathrm{pH}$ dan tipe emulsi tetapi tidak stabil pada parameter organoleptis dan daya sebar.

\section{DAFTAR PUSTAKA}

Anggraeni, C.A. 2008. Pengaruh Bentuk Sediaan Krim, Gel, dan Salep terhadap Penetrasi Aminofilin sebagai Antiselulit Secara In Vitro menggunakan Sel Difusi Franz. Skripsi. Depok : Fakultas Matematika dan Ilmu Pengetahuan Alam Universitas Indonesia.

Anonim. 1979. Farmakope Indonesia edisi ketiga. Jakarta : Departemen Kesehatan Republik Indonesia.

Dewi, T.S.P. 2014. Kualitas Lotion Ekstrak Kulit BuahManggis. Jurnal. Yogyakarta : Fakultas Teknobiologi Universitas Atma Jaya.

Mardiana, L. 2013. Ramuan dan Khasiat Ekstrak Kulit Manggis. Jakarta : Penebar Swadaya. Mitsui, T. 1997. New Cosmetics Science. Amsterdam: Elsevier.

Mutalikah, T. 2015. Mawar (Rosa Damascena Mill.) dengan Kombinasi Setil Alkohol-Asam Stearat Terhadap Sifat Fisik Dan Uji Aktivitasnya. Thesis. Surakarta : Universitas Muhammadiyah Surakarta.

Izzati, M. K. 2014. Formulasi dan Uji Stabilitas Antioksidan Sediaan Masker Peel Off Ekstrak Etanol 50\% Kulit Buah Manggis (Garcinia mangostana L.) Skripsi. Jakarta : UIN Syarif Hidayatullah.

Syamsuni, H. A. 2006. Ilmu Resep. Jakarta : Penerbit Buku Kedokteran EGC.

Tranggono, R. I dan Latifah, F. 2007. Buku Pegangan Ilmu Pengetahuan Kosmetik. Jakarta : PT Gramedia Pustaka Utama. 